\title{
Selling Lives: The Publisher Bernardo di Giunta (fl. 1518-50), Imitation and the Utilityof Intellectual Biography ${ }^{1}$
}

\section{KATHERINE M. MACDONALD}

Résumé : Cet article analyse la préface écrite par Bernardo di Giunta pour son édition des æeuvres de Christophe de Longueil, Orationes pro defensione sua, ainsi que de sa biographie anonyme (1524). Cette préface constitue un document important dans la querelle humaniste portant sur l'imitatio. La position de Bernardo effectue un mélange savant entre l'imitation comme concept stylistique et la mimesis des vertus éthiques visée par la biographie, telle que la pratique Plutarque. Finalement, cet article présente l'importance commerciale du genre biographique pour la Maison de Giunta.

$\mathrm{T}$ he Giunta family of publishers possess the reputation, among historians of the early Italian printed book, of being the intellectually inferior imitators of the rival firm of Aldus Manutius, in whose footsteps they could only seek to follow. The great nineteenth-century bibliographer Antoine Augustin Renouard makes a representative pronouncement when he says of the house of Giunta that it would have ranked as the first in its century, if the Manuzii had not existed. ${ }^{2}$ Even worse, the Giunti also stand accused of shamelessly copying the pioneering editions of Greek and Latin texts which Aldus toiled heroically to produce at his own considerable financial risk. Indeed, in 1506, the two firms were involved in a lawsuit, about which only a few tantalizing fragments of evidence survive, over Filippo di Giunta's violation of the comprehensive papal privilege issued by Leo $\mathrm{X}$ to cover Aldus' Greek and italic types. ${ }^{3}$

However, if they could not hope to touch Aldus as humanists, the Giunta certainly were in the running as businessmen. ${ }^{4}$ With two branches - one founded in 1482 by Lucantonio in Venice, the other established some ten years later by Filippo in Florence - the Giunti were well placed to service 
a large market. While Lucantonio concentrated on the more reliably profitable area of religious texts, Filippo, and later his sons Bernardo and Benedetto, were left free to explore the relatively uncertain territory of humanist books. As a centre of publishing, Florence was no match for Venice during the early $1500 \mathrm{~s}$, in either volume or quality of book production. ${ }^{5}$ Florentine printing from 1501 to 1530 was dominated by short, inconsequential works, mainly devotional in nature. ${ }^{6}$ The Giunti were able to make a name for themselves (and carve out a share of the market) by focusing on serious literary works, both classical and vernacular. ${ }^{7}$ By imitating the Aldine format (classical texts in octavo, edited to a high standard of textual correctness), the Giunti managed to bring about a small revolution in Florentine printing, effectively dragging it into the age of humanism. This decision to specialise seems to have paid off, as their presses continued to turn out fresh editions well into the seventeenth century, having enriched successive generations of Giunti along the way, whereas Aldus' firm was already struggling commercially by the $1510 \mathrm{~s} .{ }^{8}$

Of the Giunti, it is Bernardo (1487-1550), the eldest son of Filippo, who enjoys the reputation of having most closely approximated a humanist. According to one near-contemporary account of him, he possessed a more affable, urbane character and was "a better companion to authors and editors" than his father. ${ }^{9}$ In particular, his often elegantly composed prefaces to Giunta editions attest to his humanist sympathies, as well as to his own erudition. For example, Bernardo composed a particularly interesting preface for a 1524 quarto edition of the Ciceronian Christophe de Longueil's Orationes pro defensione sua. ${ }^{10}$ This edition also contained Longueil's Epistolarum libri quatuor, as well as an additional book of letters by his fellow Ciceronians, Pietro Bembo (1470-1547) and Jacopo Sadoleto (14771547). In his preface, Bernardo provides a theoretical discussion of the mechanism of literary imitation. This account of imitatio is premised on the view that it is not only desirable but necessary to know something about the life of the author in order to be able successfully to emulate his style. Literary imitation, in the form of borrowing, also operates on a practical level here, as Bernardo's remarks engage critically with the contents of another text: Plutarch's Platonizing discussion of mimesis in the preface to his Life of Pericles.

In this essay, I propose first to look in some detail, and in the context of contemporary debates on this topic, at the theory of literary imitation elaborated by Bernardo in his preface to Longueil's Orationes. Next, I shall turn my attention to the way in which Bernardo carefully adapted Plutarch's treatment of the parallel ethical issue - the imitation of moral virtue - to suit his own requirements. Finally, I shall be concerned to show how, from 
a business perspective, Bernardo's remarks provide a fascinating clue to an aspect of the Giunta publishing strategy. Most immediately, he is advertising the anonymous Vita Longolii included in the present edition of his works. But a review of the annals of the Giunta presses reveals that the scope of Bernardo's remarks is rather broader. When discussing the status and utility of literary biography, Bernardo would seem to be motivated not only by his humanist convictions, but also by a finely honed sense of business acumen.

\section{The Preface to Longueil's Orationes}

Bernardo's preface argues that intellectual biography is a useful genre because it functions as an aid to both moral and stylistic imitation of great writers. Before looking in detail at this text, which presents a highly ambiguous version of the concept of imitatio, it is worth recalling briefly some of the key elements of the Renaissance understanding of literary imitation. ${ }^{11}$ Theoretical writers on imitatio in the Renaissance closely follow the works of their ancient precursors. ${ }^{12}$ Both classical and Renaissance discussions of rhetorical imitatio/mimesis centred on two main issues. ${ }^{13}$ First, there was the question of the desirability of such imitation and the related problem of the selection of a model - an eclectic blending of authors, or the exclusive choice of a single model (e.g., Cicero for the Ciceronians). Secondly, once imitation was accepted in practice, the debate continued over the need to transcend purely verbal imitation in order to foster personal self-expression. This position was opposed to the Ciceronian view that excellence in stylistic imitation alone was sufficiently prestigious. When Bernardo composed his preface to Longueil's speeches in 1524, the most recent polemic, and the one which would have been freshest in everyone's minds, was that which had taken place in 1512 between the eclectic Giovan Francesco Pico della Mirandola (1470-1533) and the Ciceronian Bembo. ${ }^{14}$

Bernardo's preface picks up indirectly on most of these issues while simultaneously — and herein lies the ambiguity - importing a behavioural concept of mimesis as the imitation of models of virtuous conduct. The multiplicity of meanings which accrue to the term mimesis (whether understood as the imitation of other people's actions, or as the representation of life in the form of a work of art, or as the deliberate or inadvertent adoption of another writer's style) can be traced back to the ancients. Aristotle in the Poetics had advanced a view of imitation as natural to man, who learns first by mimicry, and elaborated a doctrine of mimesis as the imitation of nature in art. It was Isocrates who first applied the word mimesis to literature, giving it the specific restricted sense of rhetorical imitation (stylistic borrowing). ${ }^{15}$ It is worth observing that in many of the ancient theories of imitation, it is 
often extremely difficult to separate those strands which concern the imitation of behaviour, or pedagogic mimesis, from those which treat literary or artistic imitation. ${ }^{16}$

The text of Bernardo's preface itself can be divided roughly into four sections. First, he presents the idea that viewing an outstanding work of art automatically triggers in the onlooker an impulse to inquire after the identity of its maker. This section bears indiscriminately on all the arts - poetry, painting and sculpture - although Bernardo is specifically concerned with the graphic and plastic arts at this stage. The second section introduces the concept of imitatio. Here, Bernardo rejects painting and sculpture to focus on literature. A desire to imitate the maker is properly inspired only by literary works. Thirdly, he elaborates on the particular kind of imitation he has in mind: one which is both literary and moral. Knowledge of the life of the writer enables the individual more perfectly to imitate that life, as well as the writer's style. Lastly, Bernardo praises Longueil as the perfect model for this hybrid type of imitation. At almost every point, his stance is sympathetic to the Ciceronianism of Bembo, although, curiously, Cicero himself is nowhere mentioned.

Intellectual biography's importance and utility is the theme of the first section of Bernardo's preface. As Bernardo confides to the studious reader, he has often observed the particular manner in which cultivated men of taste and discrimination appreciate the products of art (ars) and genius (ingenium). This response takes place simultaneously at two distinct levels: not only are such connoisseurs strongly delighted ("vehementer delectentur" ["Ad lectorem," sig. aiir]), but they not infrequently take great pains to find out more about the man behind the works ("quisnam et qualis fuerit laborare" [ibid.]). Bernardo thus manages to introduce early on in the preface the fundamental critical distinction between "delectare" and "instruere": works of art may be pleasing in themselves, but the quest to learn about the man responsible for them can also lead to some form of beneficial knowledge. Exactly how this knowledge can be of benefit, Bernardo declines at this moment to explain.

Importantly for Bernardo, this curiosity about the maker is not inspired equally by all works of art. A trivial or insignificant piece tells us at a glance all we need to know about the identity of its maker, whom we may readily dismiss together with his work. Thus, intellectual or artistic biography, according to Bernardo's conception of it, should necessarily take as its subjects only those most excellent and accomplished in their field of creative endeavour. Although there is not yet any question of literary imitation in the preface, this preliminary insistence on the quality of the example recalls an important aspect of Renaissance discussions of imitatio, namely the question 
of whether to imitate a mediocre or an outstanding author. On this issue, Bernardo is resolutely in favour of the latter position, the one ultimately adopted by Bembo after a period in the wilderness imitating second-rate Latin authors. ${ }^{17}$

Bernardo goes on to assert that it is a universal response to an outstanding and skilfully made painting or statue to enquire into the condition and circumstances of its maker. If it were possible, Bernardo adds, we would also like to have the chance to meet personally with the artist and converse with him about his life in general:

Quis enim est, qui vel egregiam aliquam picturam, vel affabre factum, et elaboratum signum diutius cum delectatione contemplari possit, cui non saepius veniat in mentem de opificis conditione quaerere, aut qui etiam, si fieri posset, non libenter eum videat, colloquatur, de vitaeque totius ratione interroget? [For who is able to contemplate at length either some excellent painting or skillfully made statue and take pleasure in it, and not think to enquire after the condition of the maker? Indeed, who, if it were possible, would not gladly meet and converse with him and question him about his way of life?] (ibid.)

This attitude towards artists and authors whom one admires naturally brings to mind other early humanist compositions, such as Petrarch's famous letter to his friend, Zanobi Mazzuoli da Strada, in which he describes his retirement in Vaucluse. ${ }^{18}$ Although ostensibly withdrawn from human society, Petrarch does not want for companionship in his secluded valley. On the contrary, the presence of his library means that he might as well be in Rome or even Athens as in the south of France, and that he is able to converse as directly with Cicero or Virgil as with his intimate friends. Through his literary frequentation of his favourite authors, Petrarch claims to know their characters and minds, as well as their actions and lives; thus he is imaginatively able to address letters to them as if they were alive.

Interestingly, the fiction of establishing a personal relationship with a long-dead author is a device frequently exploited by Bernardo and his editors in their prefaces. ${ }^{19}$ For example, in the preface by Francesco Alfieri to the 1504 Filippo di Giunta octavo edition of Petrarch's Cose volgari, the editor imagines a conversation with the poet. ${ }^{20}$ Here, Petrarch redivivus, miraculously returned to his native Florence, complains to Alfieri of the poor quality of the texts of his works being published by non-Tuscan printers, and cautiously entrusts Alfieri with the patriotic task of restoring him to health by purging his works of all ineptitude and foreign words. Along similar lines are the prefaces to a 1516 quarto edition of the Decameron fictitiously addressed by "Messer Giovanni Boccaccio al lettore" and a 1519 preface written in the persona of Juvenal. ${ }^{21}$ The Roman poet tells of a visit he has received in the Elysian fields from Bacchus, who exhorts him to be of good 
cheer, as Bernardo di Giunta has at long last seen to the production of a greatly improved and emended version of his satires.

Bernardo goes on in his preface to the reader of Longeuil's Orationes to assert that no work of art can be so perfectly made that it does not leave the viewer somehow unsatisfied if he does not know the name of the artist. However excellent the work may be, so long as the viewer remains wholly ignorant of the identity of the artist, he will increasingly burn with desire to solve this troubling mystery.

In the second section of the preface, Bernardo shifts gear rather abruptly in order to make a crucial distinction between pictures and sculpture, on the one hand, and the deeds or writings which reveal a great man's genius, on the other hand. ${ }^{22}$ Biography is a worthwhile enterprise only for those subjects whose lives are found to be worth imitating as well as their works, and this, for Bernardo, would seem to exclude graphic artists and craftsmen. There is no one, he asserts, with any nobility of mind, who would wish to be Apelles or Praxiteles on seeing Coan Venus or Thespian Cupid:

Nemo enim est animo paulo nobiliori, qui si aut coam Venerem, aut thespiensem
Cupidinem, summa cum admiratione aspexerit, cum et opera ipsa, et authores maxime
probet, Apellem se aut Praxitelem esse velit, aut omnino doleat, se vel huius in
fingendo, vel illius in pingendi ratione excellentiam, non posse assequi. [There is no
one with a measure of intellectual nobility, who, were he to gaze admiringly upon
Coan Venus or Thespian Cupid, approving both the works themselves and their
authors, would himself wish to be Apelles or Praxiteles or who would be in the
slightest aggrieved that he is unable to rival the latter in sculpture or the former in
painting.] (ibid.)

The viewer should not be dismayed by the fact that he does not share the abilities of Praxiteles and Apelles in wielding a chisel or paintbrush. However, things are not the same in the case of learned and eloquent men, who are figuratively said to fashion a kind of monument which is different to the products of painting or sculpture. On acquaintance with these literary or oratorical monuments, Bernardo's noble reader is supposed to be inspired with mimetic desire on two levels simultaneously, that is, both stylistically and biographically.

The underlying premise in the third section of the preface is that, in order to imitate someone at the level of literary composition, it is first and foremost useful to know something about the life and habits of one's model:

At vero qui doctorum hominum, et eloquentium monumenta admirantur, non modo se quam simillimos illorum esse student, sed in illorum etiam si fieri possit naturam transire. Quid ergo utilius esse possit iis qui aliquem imitando effingere velint quam eius vitae consuetudinem cognitam habere? [But truly those who admire the monuments of learned and eloquent men, not only yearn to be as similar to them as possible, 
but even, if it were possible, to transform themselves into them. Therefore, what could be more useful to those who wish to imitate the artistic creations of other men than to have knowledge of their habits?] (ibid.)

Bernardo's ideal reader should not merely be eager to be as similar as possible to his learned model, but should yearn to transform himself by a fusional process into the very person of the model. These formulations provide us with a clear statement of Bernardo's position in the most current phase of the Cinquecento debate over literary imitation, which had as its chief protagonists Giovan Francesco Pico and Bembo. Here, Bernardo rejects the younger Pico's Neoplatonic emphasis on the natural talent of the individual in order to favour Bembo's view that self-expression is less important than a perfect rendition of the style of one's model. ${ }^{23}$

One important way in which Bernardo distances himself from Bembo, though, is in his Senecan equation of the style with the man. ${ }^{24}$ Whereas Bembo had famously maintained, with reference to Boccaccio, that "stilus esse optimus in vita non optima posset," 25 Bernardo's arguments here depend on the happy coincidence of stylistic and moral excellence.

Bernardo's discussion of the mechanism of imitation leads naturally to the problem of how to equal one's model. In particular, Bernardo asserts, one can learn from his biography what kind of material advantages one's model enjoyed (that is, his access to patronage), as well as the challenges and obstacles he faced. This will allow the imitator to judge his own progress on a comparative basis. This seems not dissimilar to Bembo's theoretical division of imitatio into a tripartite process of imitating, equalling and finally surpassing one's model ("imitari," "assequi," "præterire"). ${ }^{26}$

Bernardo concludes the preface with a direct address to the studious reader, which serves blatantly to advertise the biography of Longueil that he, as a caring and diligent publisher, has dutifully placed at the beginning of this edition of his speeches. Longueil's writings are certainly of the quality, Bernardo makes clear, to inspire precisely the kind of desire to know more about the author's life and doctrines that he has just finished describing:

Non enim dubito quin eius scripta legendo in eam saepe voluntatem incides, quam ante dixi eloquentium hominum, et doctorum opera inspicientibus se movere, ut libenter multa de authoris vitae ratione velis intelligere. [I do not doubt but that you may often, while reading his writings, fall into that desire which I have just said moves those who contemplate the works of eloquent and learned men, and that you should wish to understand many things about the life of their author.] ("Ad lectorem," sig. aii ${ }^{\mathrm{v}}$ )

Moreover, Bernardo continues, when we know what trials he faced and when we learn of his tragic early death, we, who may hope for longer life and more 
generous sources of funding, will take courage with regard to our own prospects for achieving feats of scholarship at least as great as Longueil's.

Bernardo's valedictory praise of Longueil touches on two other points germane to contemporary discussions of literary imitation. First, the Ciceronian Longueil is described as following in the footsteps of the ancients ("in ipsis vestigiis" [ibid.]). The image of the footprint was one of the stock images of the imitation debate, and was itself borrowed from classical treatments of the same topic (for example, by Seneca, Horace, and Quintilian). ${ }^{27}$ Bernardo's choice of expression here aligns him staunchly with the Ciceronians. Secondly, Bernardo makes the claim that it is possible to express all a Renaissance humanist might wish in Latin, even if it is now a foreign tongue and even if ancient Roman "mores" are no longer current. The proof he offers for this, naturally enough, is the example of Longueil himself. The problem of how to deal with contemporary events and modern material in correct Ciceronian Latin was a key topic in the debate over literary imitation, and Bernardo here, again not surprisingly, expresses a view similar to that of Bembo.

With respect to the author of this biography, Bernardo says only that it was written by someone who was his intimate friend ("amicissimo [...] eius, qui cum eo familiariter vixit" [ibid.]). It is interesting that Bernardo does not seem to expect the author of this Vita to inspire the kind of curiosity he describes at the beginning of the preface. In accordance with his earlier statements, we should expect that the reader of the Vita Longolii would not be able to appreciate the biography properly so long as the author remained anonymous. Paradoxically, almost the only kind of scholarly attention generated thus far by the Vita pertains precisely to the enigma of the identity of the its author. ${ }^{28}$

With his conception of the functional status of literary biography, Bernardo set the scene for a kind of "mise en abîme" of this form of writing. Longueil, who is to be admired primarily as an imitator of the ancients, is now established as a model for imitation himself.

\section{Bernardo and Plutarch's Pericles}

Bernardo's preface itself contains a practical demonstration of his concept of stylistic imitatio in the form of a significant intertextual echo of Plutarch's introduction to his life of Pericles:

No young man of good breeding and high ideals feels that he must be a Phidias or Polycleitus after seeing the statue of Zeus at Olympia or Hera at Argos, nor does he aspire to be an Anacreon or a Philetas or an Archilochus, because of the pleasure he 
derives from their poems, for it does not necessarily follow that because a particular work succeeds in charming us its creator deserves our admiration. ${ }^{29}$

Bernardo would have been familiar with this text, either in the Latin translation by Lapo Fiorentino, which circulated together with printed editions of the "variorum" translation of the Lives, or, possibly, in the Greek, of which his father had recently produced the editio princeps in $1517 .{ }^{30}$

In his preface to the life of Pericles, Plutarch is concerned with the ethical problem of selecting proper models for virtuous behaviour to imitate. ${ }^{31}$ Our natural curiosity and love of knowledge, claims Plutarch, are such that, unless we are properly trained, we risk setting our sights on the wrong kinds of models. Bernardo, too, had taken care to distinguish between this natural human curiosity, which arises when we contemplate the achievements of those inferior to us, and the proper exercise of imitation, which presumes the superiority of the model. There are, for Plutarch, certain kinds of achievements which it may please the eye to gaze upon, but which should not inspire us with the desire to imitate those responsible for accomplishing them. For example, we may enjoy perfumes and beautifully dyed textiles without wishing to adopt the lifestyle of a perfumer or garment worker, who are, lest we forget, irremediably base and lowly specimens of humanity. ${ }^{32}$ No young man of good breeding and high ideals should desire to become Phidias or Polycleitus after seeing Olympian Zeus or Argive Hera. Thus far, Bernardo agrees with Plutarch: "Nemo enim est animo paulo nobiliori, qui [. . .] Apellem se aut Praxitelem esse velit" ("Ad lectorem," sig. aiir).

However, it is evident from the continuation of Plutarch's passage that Bernardo has diverged significantly from his own model. By adding the examples of the poets Anacreon, Philetas, and Archilochus to those of the sculptors he has already mentioned, Plutarch places literary creation on a level with the plastic and graphic arts; neither sort of creation is capable of arousing the spirit of emulation or of sparking any passionate will to imitate their makers. Bernardo had made a stark distinction between the visual arts and works of scholarship and literature, which, for him, were worthy objects of imitation, both in themselves and insofar as they lead us to investigate the biographies of their authors.

For Plutarch, the only thing capable of triggering mimetic desire is the contemplation of virtuous actions, either as a direct spectator or in the form of biographical narration. Even then, imitation should not be slavish copying of one's model, without any intellectual reflection. Rather, it should be understood as the moral mechanism behind good actions. Thus it enables one to act virtuously even in disparate situations. As we have seen, Bernardo also allows for discordance between the model and the imitator. However, 
his ideal is ultimately the Ciceronian one of linguistic fusion between pupil and model author, coupled with identification on the biographical level: in Bernardo's view, reading about an author's life forms an integral part of the appreciation of his work.

But if Bernardo is prepared to distance himself from an authority such as Plutarch on this matter, he is not thereby recklessly casting himself outside of the protection of the ancients. Rather, in lending his support to intellectual biography and, in particular, by arguing for its moral utility, Bernardo places himself in the tradition of another ancient practitioner of biographical writing familiar to fifteenth-century readers: Diogenes Laertius. This tradition is best illustrated by the Veronese Benedetto Brognolo (1427-1502), who composed an epistle addressed to his Venetian pupils Lorenzo Zorzi and Jacopo Badoer for Jenson's 1475 folio edition of Ambrogio Traversari's translation of Diogenes' De vita et moribus philosophorum. ${ }^{33}$ Brognolo's preface was frequently reprinted in subsequent editions throughout the sixteenth century. In it, he assumes a response to reading ancient Greek texts which is strikingly similar to that described by Bernardo. This type of reaction can occur when reading medical texts - for example, some work of Hippocrates or another ancient medical authority:

[. . .] flagrunt cupiditate interdum ut sciant quae fuerit patria eorum, qui maiores, et reliqua quae ad ipsorum vitam pertineant. [(readers) burn with desire to know the authors' birthplaces, their ancestors and anything else that might pertain to their lives.] ${ }^{34}$

Brognolo goes on to point out how a reader's curiosity about the writer's life should be an even more important feature of the experience of reading the works of the ancient philosophers. After all, these men had the care of the soul, whilst the physicians treated only bodily ailments. Indeed, if we should discover any moral stain on their lives, Brognolo admonishes us to steer clear of their works in future as potentially damaging to our moral well-being.

It is interesting that Bernardo should have chosen this passage from Plutarch on which to calque his own discussion of the utility of intellectual biography for both moral and stylistic imitation. The Pericles preface clearly enunciates Plutarch's snobbish disdain for the mechanical arts - not only perfumery and dyeing, but sculpture and painting too. Richardson has pointed out how printing, during the sixteenth century, was classed as a "plebeian" business: mechanical, dirty and driven primarily by a desire for monetary gain. ${ }^{35}$ Printers in the Cinquecento were generally deemed by their contemporaries to be low class and unlettered. By echoing Plutarch's snobbery, Bernardo is thus ironically able to counter such accusations of crass 
ignorance. But, as we shall see in the next section, despite his show of erudition, as a businessman, he never loses sight of the potential commercial value of biography.

\section{The House of Giunta and Biography}

Bernardo's decision to use his preface to champion intellectual biography has particular significance for the Giunti as publishers, apart from the humanist polemics of literary imitation. Biography was a genre which enjoyed rapid expansion in the Italian Renaissance. ${ }^{36}$ While it is extremely difficult to establish its commercial viability with any precision, either absolutely or with respect to other genres, it is reasonable to suppose that the quantity of such titles produced was a response to demand on the part of the reading public. ${ }^{37}$ Certainly Bec's study of the books owned by Florentine individuals during the Quattro- and Cinquecento shows that biography is reasonably well-attested on the shelves of private Florentine libraries. ${ }^{38}$ For the first half of the sixteenth century, Bec's tables of book ownership reveal the presence of Plutarch and Suetonius. Plutarch in particular moved up in rank from tenth to eighth on Bec's list of the books most frequently found in private collections in the latter part of the Cinquecento. Indeed, Bec singles out Plutarch as an author who enjoyed a "succès rapide" in the period. Florentine readers' fondness for Plutarch is likely to have induced them to purchase modern works of biography as well. Biographical works by Giovio and Vespasiano da' Bisticci are documented in private libraries during the second half of the sixteenth century. ${ }^{39}$ With regard to literary lives, Bec also notes that Cosimo I possessed a Vita di Dante. ${ }^{40}$ Bec describes Florentine libraries of the early part of the sixteenth century as open to "l'actualité culturelle" and characterized by "diversité et modernité." 41 Florentine publishers of the time were acutely aware of their clientele's taste for novelty and variety. Richardson has pointed out that publishers often asked their editors to compile material about the life of the writer for inclusion in editions of both classical and modern authors. Biography, together with other exegetical material, such as glosses, indices and commentaries, could then be advertised as a selling point in new editions. ${ }^{42}$

Biography, in all its guises, formed a significant component of the output of both Filippo's and Bernardo's presses. ${ }^{43}$ Although the Giunti were far from unique in their devotion to biographical texts, they certainly exploited the genre to the full. Comparison with the production of the publishing house of Manutius shows that, while the Giunti (with at least one notable exception) were not innovators in their biographical publications, they do measure up very favourably in the variety and number of titles they 
produced ${ }^{44}$ Both the house of Manutius and the Giunti publish a similar number of works of ancient biography (Plutarch, Suetonius, Philostratus) during the first quarter of the sixteenth century. Aldus had set a precedent with the life of Aristotle included in his 1497 edition of the Metaphysics; the Giunti, following closely behind, started to include authors' biographies from $1503 .{ }^{45}$ The Giunti compensate for this time lag by the greater variety of authors for whom they provide liminary biographies: twenty-one, as opposed to nine for Aldus.

As has been mentioned, the Giunti produced the editio princeps of the Greek text of Plutarch's Lives. This impressive folio contains a prefatory epistle by Filippo thanking his illustrious friend Marcello Virgilio for lending him the manuscript used to establish Plutarch's text. In it, Filippo eulogizes Virgilio, First Chancellor and state censor, as a Florentine citizen in terms which recall Plutarch's own praise for some of his republican heroes. As is typical of the interpretation of Plutarchan biography in the period, Filippo's preface emphasizes the active moral usefulness of biography for its reader, who is encouraged to model his own life on the examples he reads about in the Lives:

propter infinita tot illustrium, romanorum, graecorumque virorum exempla quae in illis passim inveniuntur, optimum vitae suae institutum esse aquisitaturum. [On account of the infinite number of examples of illustrious Greeks and Romans which will be found in them (Plutarch's Lives), an excellent custom of life is to be acquired. $]^{46}$

In addition to Plutarch, the Giunti also produced editions of several other ancient biographical collections devoted to public figures, including Suetonius' Lives of the Twelve Caesars (1510), the De viris illustribus in re militari et administranda republica then attributed to Pliny (1515), and the series of emperors' biographies issued under the title De Caesaribus libri III ("Scriptores Historiae Augustae," 1519). With respect to Greek authors, there is a 1521 Giunti edition of Jacopo di Poggio's Italian translation of Xenophon's Life of Cyrus. The Plutarchan model also lent itself to pastiche by Renaissance humanists, as, for instance, in Pier Candido Decembrio's parallel accounts of Caesar and Alexander the Great - one of the comparisons missing from Plutarch — reproduced in the 1519 Giunta edition of Decembrio's translation of the History of Alexander by Quintus Curtius Rufus. ${ }^{47}$ Bernardo prefaced this work with an epistle to the Florentine patrician Francesco Guidetti, in which he specifically calls attention to the addition of this comparison. Bernardo writes that it has been included to satisfy Guidetti's predilection for "simili lezioni," by which we may under- 
stand Plutarchan-style biography. ${ }^{48}$ Bernardo's remarks here attest a businessman's keen awareness of the contemporary vogue for biography.

Contemporary statesmen could also be the subject of biography, and the Giunti began to cater for the growing interest in such works with their editions of Machiavelli's Vita di Castruccio Castracani (1532) and Paolo Giovio's life of Muzio Attendolo Sforza in Ludovico Domenichi's Italian translation (1549).

Yet if biography in general was commercially important to the Giunti, the specific category of lives of writers and intellectuals was perhaps even more so. One of the most successful authors in the Giunti stable - to use this most unciceronian of expressions — was Pietro Crinito (1474-1507). In 1505, his collection of biographies of the Latin poets from Livius Andronicus to Theodosius, the De poetis latinis, first emerged from the presses of Filippo Giunta. ${ }^{49}$ The work was to become an enormous best-seller by sixteenth-century standards, to judge from the number of reprints over the next decades. It had already been cunningly advertised in the 1504 first edition of the same author's Commentarii de honesta disciplina as forthcoming from the same publishers. Even before this date, the Giunti had been whetting the public's appetite for Crinito's literary lives by including them in their editions of the Latin poets. Only the third work to be printed by Filippo, in 1503, was an edition of the poems of Catullus, Propertius and Tibullus. This pocket-sized octavo edition was a blatant copy of the Aldine edition in both its format and the text it reproduced. However, the Giunti edition had something which the Aldine did not: biographies of the three poets by Crinito. Editions of Valerius Flaccus and Terence published by the Giunti before the De poetis latinis similarly feature a preview of Crinito's collection. Also worth mentioning in this connection is a 1503 edition of Sallust's De coniuratione Catilinae with a life of the writer extracted from a larger work by Crinito with the title De historibus ac oratoribus. This latter collection of biographies of historians and orators by Crinito was to remain unpublished (and perhaps also unfinished) and is now lost.

The Giunti were not restricted to Crinito as a source for biographies of men of letters. There is a 1519 edition of Ovid's works which contains a life of the poet "ex ipsius libris excerpta." 50 Other humanist biographies of ancient authors also figure in Giunti editions, for instance, the life of Homer by Andrea Dazzi and that of Suetonius by Mariano Tucci, a cleric who had worked as editor and corrector for the Giunti from 1510 to 1514. It was extremely common among sixteenth-century editors and publishers to pillage Diogenes Laertius for Lives of philosophers to fill out editions of their works, and the Giunti were no exception. A 1527 edition of Xenophon in Latin translation has a life of Xenophon taken from Diogenes Laertius. ${ }^{51}$ 
As with the biographies of public figures, contemporary poets also became the focus of increasing biographical interest during the Cinquecento, and the Giunti were ready to cater for this as well. An anonymous biography of the court poet, musician and protégé of Isabella d'Este, Seraphino Ciminelli (1466-1500), known as l'Aquilano, is to be found in the 1516 Giunti edition of his verse. However, it does seem odd that the Giunti editions of those "modern" poets whose lives received the greatest such attention in the early years of printing - Dante, Petrarch and Boccaccio - did not contain biographies..$^{52}$

Despite the reservations expressed by Bernardo in the Longueil preface about biographical enquiry directed at painters and sculptors, artists' lives, too, were no strangers to the Giunti presses. In 1504, the year before the publication of Crinito's De poetis, the Giunti may also have produced the first edition of Pomponio Gaurico's De sculptura, which included his De claris sculptoribus. ${ }^{53} \mathrm{We}$ should recall in passing that the House of Giunta would much later go on to publish a work of tremendous influence in this field: the 1568 second edition of Giorgo Vasari's Le vite de piu eccellenti architetti, pittori, et scultori italiani, which was the first to include woodcut portraits of the artists, as well as of Vasari himself.

Thus, it emerges that the Giunti would have had strong business reasons to argue for the desirability and utility of biography, and in particular of literary lives. In trumpeting the Vita Longolii, Bernardo also implicitly puts in a plug for all other Giunti editions similarly prefaced with biographies, as well as for literary biography in general. Certainly, a general awareness of the importance of marketing and commercial considerations is not infrequently to be detected in Giunti prefatory texts. In his preface to the Giunti Sophocles of 1522, Bernardo claims that his burning love for this purest of authors is the reason behind his care to ensure the best possible text of the tragedies. However, he is not unaware of the happy commercial consequences of so scrupulous an editorial policy. According to Bernardo, the Greek editions the Giunti produce to such a high standard of accuracy have literally flown off the shelves:

et libros ipsos cupidissime a studiosis arripi videbamus: ut brevi, ex magnorum illorum librorum copia, perpauci reliqui nobis forent [and we have seen those very books being snapped up most eagerly by scholars in such a way that in a short period of time, out of a great pile of books, we should be left with a very few]. ${ }^{54}$

However, it would be unfair to Bernardo to represent him as being entirely driven by the desire to sell books. Bernardo himself certainly liked to emphasise his lofty, idealistic side and his sympathy with the concerns of the humanists whose works he published. For instance, in the preface 
addressed to his fellow "studiosis" contained in his father's edition of works by Philostratus, Bernardo explains his publishing policy in strongly idealistic terms. ${ }^{55}$ Just as men plant seedlings without any hope of seeing the trees grow to maturity, so Bernardo labours over his editions of Greek and Latin authors, in the hopes that he will thus be responsible for planting the germs of wisdom in contemporary adolescents. Yet even when Bernardo seems financially disinterested, he displays a typically humanist awareness of a different kind of personal advantage to be obtained from his endeavours. In a 1515 edition of rhetorical treatises by Ausonius and Hermogenes, Bernardo claims that if he is exacting about the accuracy of the texts he produces, it is not only in order that he might be useful to scholars, but also out of a sense of personal glory. Writing to his fellow Florentine, Lorenzo Benivieni (1495-1547), Bernardo waxes lyrical: "ut [. . .] et mihi quoque viam pararem, qua me quoque possem tollere humo, victorque volitare per ora" ["in order that (...) I may prepare a way for myself too, by which I too might lift myself up off the ground, and, victorious, fly from mouth to mouth"]. ${ }^{56}$ There is no reason to doubt the sincerity of such statements of Bernardo's humanist convictions. Still, it is not incidental to our present purposes to mention that in the case of the 1517 Philostratus, we are dealing with a work with a biographical component, as the edition also included Philostratus's Lives of the Sophists.

To sum up, then, the Longueil preface can be read on one level as a late document in the Renaissance debate about imitatio, one which comes at a time when the major questions, at least as far as Latin was concerned, had been resolved in favour of Bembo's Ciceronianism. However, the matter is not as cut-and-dried as it might seem. For Bernardo also here effects a fusion between the idea of imitatio as the stylistic reproduction of a literary model and the concept of mimesis which is concerned with imitating life and which is a topos of biographical writing. Bernardo has deliberately blurred the boundaries between these two separate critical issues in a way which suits his publishing strategy: literary texts edited to a high standard of correctness (and thus suitable for imitation) and including author biographies.

University College, London

\section{Notes}

1. I am grateful to two anonymous readers at Renaissance and Reformation/Renaissance et Réforme for their helpful criticism and suggestions for the revision of this article.

2. In a similar vein, Renouard also describes the Giunti as "fort instruits sans être des savants du premier ordre" (A. A. Renouard, "Notice sur les Junte et liste sommaire de 
leurs éditions jusqu'en 1550," in Annales de l'imprimerie des Alde, ou histoire des trois Manuce et de leurs éditions, 2nd ed., vol. 3 [Paris: P. Renouard, 1825], p. iii).

3. On this dispute, as well as on the relationship between the two rival firms in general, see Martin Lowry, The World of Aldus Manutius: Business and Scholarship in Renaissance Venice (Oxford: Basil Blackwell, 1979), esp. pp. 156-58.

4. Even Renouard allows them this: "Très habiles, et même savants typographes, meilleurs commerçants que les Manuce, ils ont fait d'utiles et importantes éditions" (p. v). For a detailed (but not entirely reliable) history of their business, see William A. Pettas, The Giunti of Florence: Merchant Publishers of the Sixteenth Century (San Francisco, CA: B. M. Rosenthal, 1980). A comprehensive bibliography of Florentine Giunti editions is to be found in Decio Decia, I Giunti tipografi editori di Firenze 1497-1570, ed. Renato Delfiol (Florence: Giunti Barbera, 1978), which complements A. M. Bandini, Juntarum Typographica Annales (Lucca, 1791). Bandini also conveniently reproduces extracts from many Giunti prefaces and provides details of addressees.

5. For a comparative analysis of the output of publishing centres in Italy during this period, see A. Quondam, "La letteratura in tipografia," in Letteratura italiana. Produzione e consumo, vol. 2 (Turin: Einaudi, 1983), pp. 555-686, esp. 573-86. On the conditions faced by Florentine publishers at the turn of the century, see R. Ridolfi, $L a$ stampa a Firenze nel secolo XV (Florence: Olschki, 1958).

6. Brian Richardson, Print Culture in Renaissance Italy: The Editor and the Vernacular Text, 1470-1600 (Cambridge: Cambridge University Press, 1994), p. 79.

7. Ibid., pp. $79-80$.

8. On the progressive financial decay of Aldus' firm from 1502 to 1510, see Lowry, pp. 149-67.

9. Donato Giannotti, in a letter to Piero Vettori composed some sixteen years after Bernardo's death, calls him a "migliore compagno," in contrast with his father Filippo, who is unflatteringly termed an "asino" (Lettere à Piero Vettori, ed. R. Ridolfi and C. Roth [Florence: Vallecchi, 1932], p. 142; cited by Pettas, p. 83).

10. "Bernardus Junta ad lectorem," sig. aii ${ }^{\mathrm{r}-\mathrm{v}}$ in Christophe de Longueil, Orationes pro defensione sua (Florence: Heirs of B. Giunta, 1524; fac. rpt. Farnborough: Gregg Press, 1967). Subsequent references to Bernardo's preface ("Ad lectorem") will be documented in the body of the essay; the translations furnished are my own.

11. On this topic see the excellent work by Martin L. McLaughlin, Literary Imitation in the Italian Renaissance: The Theory and Practice of Literary Imitation in Italy from Dante to Bembo (Oxford: Clarendon Press, 1995). For a French comparison, see A. Moss, "Literary imitation in the Sixteenth Century: Writers and Readers, Latin and French," in The Cambridge History of Literary Criticism, vol. 3 (The Renaissance), ed. Glyn P. Norton (Cambridge: Cambridge University Press, 1999), pp. 107-18.

12. On classical discussions of imitatio, see especially D. A. Russell, "De imitatione," in Creative Imitation and Latin Literature, ed. David West and Tony Woodman (Cambridge: Cambridge University Press, 1979), pp. 1-16.

13. See Russell, p. 5, and McLaughlin, Literary Imitation, p. 22.

14. McLaughlin, Literary Imitation, pp. 249-74.

15. Aristotle, Poetics, 1448b; Isocrates, Adversus Sophistas, 14-18. Cf. McLaughlin, Literary Imitation, p. 5. 
16. The confusion of these two concepts of pedagogic and literary mimesis in ancient writings is noticed in particular by Thomas M. Greene, The Light in Troy: Imitation and Discovery in Renaissance Poetry (New Haven, CT: Yale University Press, 1982), p. 54.

17. McLaughlin, Literary Imitation, p. 263.

18. Petrarch, Epistolae familiares, 15, 3, ed. Vittorio Rossi, vol. 3 (Florence: G. C. Sansoni, 1937), p. 139, 11. 14-15.

19. On the strategy of including a letter or poem by a long-dead author, see Richardson, p. 12.

20. Petrarch, Le Cose volgari di Messer Francesco Petrarcha (Florence: Filippo di Giunta, 1504). Alfieri's preface is on the verso of the title page. This edition copies Bembo's 1501 edition for Aldo Manuzio.

21. Giovanni Boccaccio, Il Decamerone di Messer Giovanni Bocchaccio (Florence: Filippo di Giunta, 1516); Juvenal and Persius, Ju. Juvenalis una cum Au. Persio nuper recogniti (Florence: Heirs of Filippo Giunta, 1519, $8^{\circ}$ ).

22. The rivalry between the visual arts and literature was a commonplace in Renaissance discussions of imitation. $C f$. Bembo's comparison of imitation of the ancients as practised by contemporary artists, such as Michelangelo and Rafael, and as practised by men of letters. Bembo argues that we should strive to imitate, not the fragments of marble statuary scattered around modern Rome, but rather "le imagini e le forme, che gli antichi uomini ci hanno de' loro animi e del lor valore lasciate, ciò sono le scritture" (Pietro Bembo, Prose della volgar lingua, ed. M. Marti [Padua: Liviana, 1955], p. 98).

23. See McLaughlin, Literary Imitation, pp. 255-57 and 265.

24. "Talibus hominibus fuit oratio qualis vita" (Seneca, Ad Lucilium epistulae morales, ed. Richard M. Gummere, Loeb Classical Library, vol. 3 [London: Heinemann; New York: Putnam, 1925], Letter 114, p. 300).

25. Cited by McLaughlin, Literary Imitation, p. 264.

26. Ibid.

27. See McLaughlin, Literary Imitation, pp. 28, 31, 258, 260 et passim.

28. See the articles of G. B. Parks, "Did Pole write the Vita Longolii," Renaissance Quarterly 26 (1973): 274-85, and A. Vos, "The Vita Longolii: Additional Considerations about Reginald Pole's Authorship,” Renaissance Quarterly 30 (1977): 324-33.

29. Plutarch, "Pericles," in The Rise and Fall of Athens: Nine Greek Lives, trad. Ian Scott-Kilvert (Harmondsworth: Penguin, 1960), p. 166.

30. On the editorial history of Plutarch's Lives in this period, see V. R. Giustiniani, "Sulle traduzioni latine delle Vite di Plutarco nel Quattrocento," Rinascimento, 2nd ser., 1 (1961): 3-62.

31. Plutarch, "Pericles," ed. cit., pp. 165-66. On this preface and its significance for the interpretation of Plutarchan biography, see Philip A. Stadter, A Commentary on Plutarch's Pericles (Chapel Hill, NC: University of North Carolina Press, 1989), as well as Alan Wardman, Plutarch's Lives (London: Paul Elek, 1974), pp. 20-25.

32. Plutarch, "Pericles," ed. cit., p. 166.

33. Benedetto Brognolo, "Benedictus brognolus generosis patriciis nenetis Laurentio georgio: Jacoboque baduario salutem plurima dicit," in Diogenes Laertius, Vitae et sententiae philosophorum (Venice: N. Jenson, 14 August 1475), fols. $2^{\mathrm{v}}-3^{\mathrm{r}}$. Brognolo 
worked as a corrector for N. Jenson in Venice, where he taught Greek and Latin for over fifty years. On Brognolo, see Mario Emilio Cosenza, Biographical and Bibliographical Dictionary of the Italian Humanists and of the World of Classical Scholarship in Italy, 1300-1800, 4 vols. (Boston: G. K. Hall, 1962), 4: col. 2964-65.

34. Brognolo, fol. $2^{\mathrm{v}}-3^{\mathrm{r}}$.

35. Richardson, p. 11. He cites in particular Anton Francesco Doni's dialogue I Marmi (ed. E. Chiòrboli, 2 vols. [Bari: Laterza, 1928], 1: 177), in which a character describes the marginal social status of printers.

36. Martin L. McLaughlin, "Biography and Autobiography in the Italian Renaissance," in Mapping Lives: The Uses of Biography, ed. Peter France and William St. Clair (Oxford: Oxford University Press for The British Academy, 2002), pp. 37-66. On the number of biographies produced in the period 1350-1550, see esp. pp. 37-38 and 64 .

37. On the role of the new technology of print in shaping the production of literary works according to genre typology, see Quondam, pp. 676-84. See also Rudolf Hirsch, Printing, Selling and Reading, 1450-1550 (Wiesbaden: Harrassowitz, 1967).

38. Christian Bec, Les livres des florentins (1413-1608), Bibioteca di "Lettere italiane," 29 (Florence: Olschki, 1984), pp. 56-103.

39. Ibid., pp. 61 and 85.

40. Ibid., p. 103.

41. Ibid., p. 56. Richardson corroborates this view, describing Florentine literary tastes as "sophisticated" (p. 79).

42. Richardson, p. 3. A similar observation is made by McLaughlin, "Biography," who also points out that the lives of writers included in new editions of their works were often devoid of critical spirit and intent on extolling their subjects' virtues because "print culture aims to sell the work, not put off potential buyers" (p. 56).

43. $11 \%$ of the books published by the Giunti from $1497-1525$ contain a biography as a paratext; the percentage of biography increases to $15 \%$ when works of free-standing biography (collections and individual lives) are added. The figures for the House of Manutius during the same period (after the death of Aldo in 1515, the firm continued, during Paolo's minority, under the direction of André d'Asola) are: 7\% editions with biography; $3 \%$ free-standing biography. See Table 1 for a list of editions of biographical works published by the Giunti (including editions containing a life of the author) and Table 2 for an overall breakdown of the Giunti's output according to genre.

44. It should be recalled here that during the period 1497-1525, the total output of the Giunti presses was 189 titles, as compared to 239 for the House of Manutius.

45. The habit of including authors' biographies with their works derives, of course, from manuscript tradition. Other writers whose biographies Aldus included in his editions are Lucan (1502), Thucydides (1502, by Marcellinus), Ovid (1502, by Andrea Navagero), Homer (1504, lives by pseudo-Plutarch and pseudo-Herodotus), and Demosthenes (1504, two lives by Libanius and Plutarch).

46. Filippo Giunta, "Marcello Virgilio Rei. p. Florentinae a secretis Philippus Junta S.," in Plutarch, Vitae Romanorum et Graecorum (Florence: Filippo Giunta, 1517), sig. aii ${ }^{\mathrm{r}}$.

47. Quintus Curtius Rufus, Historia d'Alessandro Magno [. . .] tradotta in vulgare da P. Candido (Florence: Heirs of Filippo Giunta, 1519, $8^{\circ}$ ). 
48. "Bernardo di Philippo di Giunta a Francesco Guidetti Patritio Fiorentino S.," in Rufus, sig. aiir.

49. Pietro Crinito, De Poetis latinis (Florence: Filippo Giunta, 1505, fol.).

50. Ovid, P. Nasonis vita ex ipsius libris excerpta. Heroidum. Epistulae. Amorum libri iii (Florence: Giunta, $1519,8^{\circ}$ ). This edition copies the one by the House of Manutius (1515).

51. Xenophon, Opera quae extant (Florence: Heirs of Filippo Giunta, 1527, fol.). $C f$. the Greek Xenophon published by the House of Manutius with the life of the philosopher by Diogenes Laertius (1525).

52. For a discussion of early biographies of Petrarch, Dante and Boccaccio, see McLaughlin, "Biography," pp. 46-56. See also C. A. Madrignani, "Di alcune biografie umanistiche di Dante e Petrarca," Belfagor 18 (1963): 29-48.

53. This edition is listed as "uncertain" in the catalogue provided by Decia, pp. 68-69.

54. "Bernardus Juncta Lectori salutem," in Sophocles, Tragediae (Florence: House of Giunta, 1547, $\left.4^{\circ}\right)$, sig. aaiii.

55. "Bernardus Junta a studiosis," in Philostratus, Eikones (Florence: Filippo di Giunta, 1517, fol.), sig. aiir ${ }^{\mathrm{r}}$.

56. "Bernardus Junta Laurentio Benevenio SPD," in Ausonius and Hermogenes, Ausonii Sophistae praeludia. Hermogenis Rhetorica (Florence: Filippo Giunta, 1515, $8^{\circ}$ ), sig. aiir ${ }^{\mathrm{r}}$.

\section{Table 1}

GIUNTI EDITIONS OF MiLITARY BIOGRAPHY

1510 SuETONiUs. De vita Casarum. $8^{\circ}$ (contains Tranquilli vita by Mariano Tucci)

1517 PlutARCh. Vitcr. Gk. fol.

1515 PLINY. De viris illustribus in re militari et administranda rep. $8^{\circ}$

1519 SCRIPTORES HistoriÆ Augustæ. $8^{\circ}$

1519 Quintus Curtius Rufus. Historiae Alexandri Magni (Parallelo di Cesare e Alessandro Mago, by Pier Candido Decembrio). $8^{\circ}$

1521 Xenophon. Vita di Cyro tr. da J. di M. Poggio Fiorentino. $8^{\circ}$

1532 MaChIAVEll. Vita di Castruccio Castracani. $4^{\circ}$

1549 Giovio. La vita di Sforza, tr. by L.Domenichi. $8^{\circ}$

\section{GIUNTI EDITIONS OF INTELLECTUAL BIOGRAPHY (INCLUDING EDITIONS WITH AN AUTHOR BIOGRAPHY BUT EXCLUDING REPRINTS) \\ 1503 Catullus, Propertius, Tibullus (with lives by Crinito). $8^{\circ}$ \\ 1503 VAlerius FlacCus. Argonauticon (with life by Crinito). $8^{\circ}$ \\ 1504 SALLUST (with life by Crinito from lost De historicis ac oratoribus). $8^{\circ}$ \\ [1504 GAURICO. De sculptura (with De claris sculptoribus). $\left.8^{\circ}\right]$ ed. incert. \\ 1505 CRINITO. De poetis latinis. fol.}


24 / Renaissance and Reformation / Renaissance et Réforme

1505 TERENCE (with life by Crinito). $8^{\circ}$

1506 SENECA. Tragediae (with life by Crinito). $8^{\circ}$

1512 LUCRETIUS (with life by Crinito). $8^{\circ}$

1513 JuVENAL, PERsius (with lives by Crinito). $8^{\circ}$

1514 HORACE (with life by Crinito). $8^{\circ}$

1515 SUETONIUS. De claris grammaticis ac Rhetoribus. $8^{\circ}$

1515 ARISTOPHANES (with Gk. life of Aristophanes). Gk. $8^{\circ}$

1516 SERAPHINO CIMINELLI (with anonymous Vita del Serafino). $8^{\circ}$

1517 Ausonius (with life by Crinito). $8^{\circ}$

1517 Philostratus. Vita sophistorum. Gk. fol.

1519 CLAUDIAN (with life by Crinito). $8^{\circ}$

1519 HOMER (with Vita di Omero by Andrea Dazzi). Gk. $8^{\circ}$

1519 OvID (with P. Nasonis vita ex ipsius scripta excerpta). $8^{\circ}$

1524 LONGUEIL (with anonymous Vita Longolii). $4^{\circ}$

1527 XENOPHON (with Vita Xenophontis from Diogenes Laërtius). fol.

1568 VASARI. Le Vite de' piu eccellenti pittori, scultori, e architettori (2d ed.; first illustrated ed.). fol.

Table 2

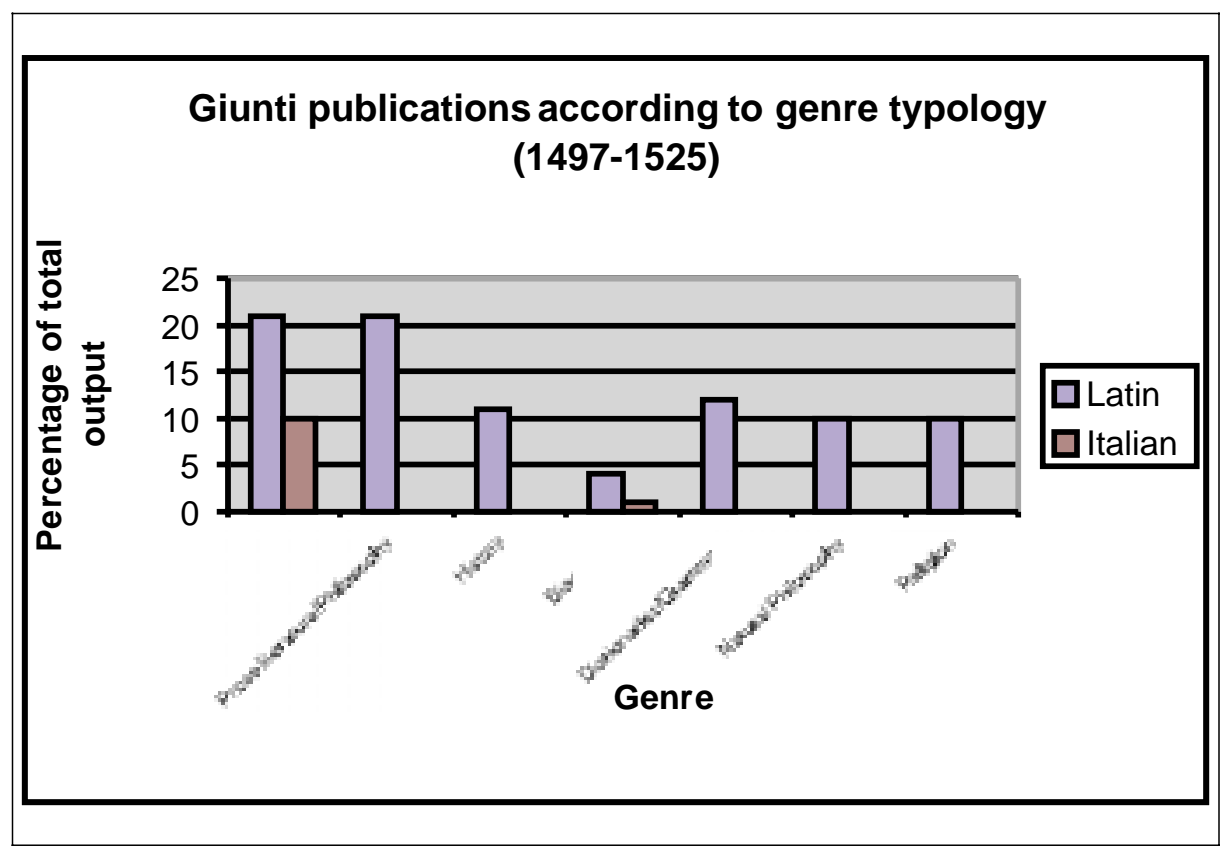

